\title{
7 \\ CONSCIOUSNESS AND THE MIND-BODY PROBLEM IN INDIAN PHILOSOPHY
}

\author{
Christian Coseru
}

\section{Introduction}

The thriving contemporary enterprise of Consciousness Studies owes its success in large measure to two late 20th-century intellectual developments in cognitive science and its allied philosophy of mind: a growing interest in the study of the neurobiological processes that underlie consciousness and cognition, and the rehabilitation of first-person approaches to the study of consciousness associated with the 20th-century European tradition of phenomenological philosophy. The first development marks a shift away from preoccupations with the status of mental representation to understanding the function of perception, attention, action, and cognition in embodied and enactive, rather than purely representational, terms. The second acknowledges the importance of fine-grained accounts of experience for the purpose of mapping out the neural correlates of consciousness. Both developments recognize that empirical research is essential to advancing any robust philosophical and scientific theory of consciousness. At the same time, these developments also open up the possibility that there may be aspects of consciousness that are not empirically tractable, aspects whose understanding require that we revise the way we conceptualize both the easy and hard problems of consciousness. It is this revisionary approach that has opened the door to systematic contributions to the study of consciousness that take its phenomenological and transcendental dimensions seriously.

Indian philosophy is host to a rich tradition of such systematic examinations of consciousness that focus primarily, though not exclusively, on its phenomenological and transcendental dimensions. Indeed, one could go as far as to argue that the nature and function of consciousness is perhaps the single most contentious issue among the different schools of Indian philosophy, a development without parallel in the West, prior to Descartes, Kant, and the British empiricists. From its earliest association in the Upanișads with the principle of individuation or the self (ätman), to its indispensability to any theory of knowledge, the concept of consciousness (variously rendered in Sanskrit as cit, citta, vijñanna) has been at the center of debates about personal identity, agency, and the grounds of epistemic reliability. Not only are analyses of the different aspects of consciousness essential to the problem of self-knowledge, they are also fundamental in settling metaphysical claims about the nature of reality (Siderits 2015). Much of the debate follows the familiar terrain of inquiries into such pressing matters as the reach of perception, the nature of mental content, and the character of veridical states of cognitive awareness. But the tradition is also 
host to a vast repertoire of first-person methods and to a rich vocabulary of phenomenal concepts meant to capture dimensions of consciousness that are not ordinarily available to empirical scrutiny.

Considering the sheer amount of literature associated with the exploration of consciousness in Indian philosophy, coming anywhere near a comprehensive survey within the limits of this chapter would be impossible. I have therefore chosen to focus on a range of methodological and conceptual issues, drawing on three main sources: (i) the naturalist theories of mind of Nyāya andVaiśeșika, (ii) the mainly phenomenological accounts of mental activity and consciousness of Abhidharma and Yogācāra Buddhism, and (iii) the subjective transcendental theory of consciousness of Advaita Vedānta. The contributions of Indian philosophers to the study of consciousness are examined here not simply as a contribution to intellectual history, but rather with a view to evaluating their relevance to contemporary issues, specifically to the mind-body problem.

It is worth noting from the outset that there are no explicit articulations of the Cartesian mind-body problem in Indian philosophy. In India, defenders of metaphysical dualism operate with conceptions of substance that do not admit of a strict dichotomy between res extensa and res cogitans. Dualist schools of thought such as Sāṃkhya, for instance, take substance (dravya) to be reducible neither to the category of quality (guna) nor to that of action (karman). On this view, matter has emergent properties but lacks internal dynamism, which is provided by the activity of consciousness. And while pure consciousness itself lacks extension, in the process of being and becoming, it reaches out (or 'extends') into the world through reason, experience, and the ability to entertain first-person thoughts. Similarly, for Nyāya and Vaiśeșika thinkers following in the footsteps of Jayanta Bhatta (fl. 850 C.E.), Bhasarvajña (fl. 950 C.E.) and Udayana (fl. 1050 C.E.), selves can be said to have extension (vibhu), by virtue of possessing a rather unique property known as pervasion (vyāpti). Furthermore, the conception of mind (manas) at work in Indian philosophy differs in significant ways from the prevailing Cartesian notion of an immaterial thinking substance (Ganeri 2012:218-221). Mind is largely conceived as a faculty that occupies an intermediary place between the senses and the intellect, and is defined primarily in terms of its capacity to organize and integrate the raw experiential data available to conscious cognition.

Given a general preoccupation with overcoming the limitations of the human condition, conceived largely in terms of constraints imposed by our embodied condition on our psychology, the absence of the mind-body problem in Indian philosophy might seem like an inexplicable lacuna. How could Indian thinkers, prior to their encounter with European philosophy, have overlooked such an essential problem? One possible answer would be to make the case that, as stated, the problem can only arise in the context of scientific discoveries about human physiology and the brain, coupled with a commitment to the sort of mechanistic conception of reality prevalent in Europe at the dawn of modern science. Another possibility, which is in keeping with critics of the Cartesian legacy in contemporary philosophy of mind, is to say that the mind-body problem is really a pseudoproblem, the outcome of metaphysical commitments to some version of mechanistic dualism. But the presence of dualist positions with strong naturalist undercurrents in Indian philosophy, especially in the Nyāya and Sāmkhya traditions, rules out the possibility of treating the mind-body problem as an idiosyncratic feature of Cartesian metaphysics. As current debates in the metaphysics of mind have demonstrated, even assuming different varieties of dualism (predicate, property, and substance), there are ways of conceiving of the relation between mind and matter that avoid the Cartesian interactionist model, with new forms of hylomorphism (Jaworski 2016), psychophysical parallelism (Heidelberger 2003), and non-Cartesian substance dualism (Lowe 2006) as the main alternatives.

\section{Epistemology and the Metaphysics of Consciousness}

Is there some persistent aspect of human experience, something that originates at birth or even at conception and continues through the various stages of one's life, and perhaps beyond? 
Metaphysical speculations about the existence and nature of such an entity, known in classical Indian sources as the atman or the self, are the principal concern of the Upanișads, a group of texts in the style of Platonic dialogues composed around the middle of the first millennium B.C.E. In one of the earliest such accounts, from the Bṛhadaranyaka Upanișad (3.4.2), we come across a systematic refutation of epistemological reflexivity. The formula, which appears in several other locations in the same text, reads as follows: "You cannot see the seer who does the seeing; you cannot hear the hearer who does the hearing; you cannot think of the thinker who does the thinking; and you can't perceive the perceiver who does the perceiving" (Olivelle 1998: 83).

The view articulated here, which will eventually come to inform the subjective transcendental theory of consciousness of Advaita Vedānta (see below, Section 5), is that the principle of cognitive awareness, that which makes possible knowledge in all its modalities (perceptual, inferential, introspective, etc.), cannot itself be known or cognized by those very faculties whose cognizing it makes possible. Whether this principle is taken to be a self or consciousness itself with its intentional and subjective aspects, it is not something that can be made known or manifest. What serves as the basis for something cannot itself be made manifest or present by the very thing that it makes possible. ${ }^{1}$ Indian metaphysics of mind has it that ultimately, the nature of reality is such that it must be constituted as an immutable dimension of consciousness. To the extent that cognition is intimately connected to consciousness, then, consciousness is what ultimately makes cognition possible. If consciousness itself is what makes cognition possible, the conditions for cognition being reliable are internal to cognition itself, which suggests that the earliest Indian philosophical speculations about consciousness point to epistemic internalism.

What is it about consciousness that determines how a subject comes to have veridical experiences? Classical Indian discussions of consciousness take cognitive events to be individual states of consciousness whose epistemic status depends on the reliability of access consciousness. A cognition of blue is simply a case of consciousness taking the form of the object cognized or of having that form superimposed on it. Given the close connection between consciousness and cognition, and considering that knowledge is a matter of consciousness undergoing the sort of transformation that results in the occurrence of reliable cognitive events, epistemological concerns are never altogether absent from considerations about the nature of consciousness. If that which we call the self cannot itself be seen or thought, even though it is present whenever we see or think, then it is not something that can become an object of consciousness. As Yājñavalkya explains to his wife and philosophical interlocutor, Maitreyī, in a seminal passage of the Brhadaranyaka Upanișad (2.4.14): "When there is duality of some kind...then the one can see the other...then the one can think the other, and the one can perceive the other. When, however, the whole has become one's very self...then who is there for one to see and by what means?" (Olivelle 1998: 69). What we have here is a clear example of transcendental subjectivity: the thinker itself cannot be thought. Rather, thought, much like sensation and perception, is an irreflexive or anti-reflexive relation, at least with regard to the consciousness whose thinking episode it is.

One of the problems with the anti-reflexivity principle is that it cannot bridge the explanatory gap between the physical and mental domains. If cognition is but a transformation of consciousness, on the assumption that consciousness cannot be understood in non-phenomenal terms, it would follow that all cognitions have a distinct phenomenal character (a rather controversial position). While it is obvious that perceptual awareness has its attendant phenomenology, it is not at all clear that propositional attitudes have their own proprietary phenomenology, if at all. The fragrance of a lotus flower, the taste of freshly brewed coffee, and the bathing hues of a summer sunset are distinct phenomenal types: there is something it is like to experience them. It is not at all clear, however, that thoughts of the sort, 'Paris is the capital of France' or 'Sanskrit 
is a fusional language' have any phenomenological character: rather, they are discerned on the basis of their propositional content. Of course, one may abstract from experience the concept that coffee is an aromatic substance, but this is primarily a phenomenal concept grounded in a specific phenomenal experience (coffee drinking), not an abstract concept whose mastery depends on knowing the chemical composition of the coffea genus.

That consciousness is central to cognition, and to veridical cognition, in particular, is a commonly shared view among Indian philosophers. Disagreements arise, however, when considering whether cognition (jñāna) is just an aspect of consciousness (cit), and thus not different from it, or a distinct event in the mental stream occasioned by the availability of a particular object. One way to frame this problem is to consider the different ways in which the problem of consciousness may be conceptualized. In general, Indian philosophers operate with three distinct concepts of consciousness: (i) as a quality of the self; (ii) as an act of the self; and (iii) as identical with the self or as the self itself. Taking consciousness to be a quality of the self raises additional questions: is it an essential or merely an accidental quality, and if the latter, what are the specific conditions under which consciousness becomes manifest? (This is an issue with implications for the mind-body problem.) Likewise, the view that consciousness is an act of the self or the self itself confronts a different set of issues, mainly concerning the nature of agency, and the problem of composition and metaphysical grounding.

Unlike consciousness, whose function of illuminating or making present is unmistakable, cognition may be either true or false. Since only valid cognitions count as knowledge, the Sanskrit term for a cognition that is epistemically warranted is prama. The indubitability of conscious experience suggests that Indian philosophers by and large endorse the immunity to error through misidentification thesis: there is no mistaking the fact that one is conscious, irrespective of whether the contents of one's consciousness are reliably apprehended or not. But the immunity to error through misidentification thesis assumes that phenomenality is the unmistakable character of consciousness: to be conscious is for there to be something it is like. But this locution, at least as initially employed by Nagel (1974), assumes the presence of a subjective point of view, which is incompatible with some Indian philosophical perspectives, specifically those of Sāmphya and Vedānta, which take consciousness to be ultimately lacking any structure.

The analysis that follows considers three different approaches to the problem of how consciousness and cognition are related, and its implications for the mind-body problem and the problem of personal identity.

\section{Consciousness as an Attribute of the Self: Nyāya Naturalistic Dualism}

If knowledge is an epistemic relation, the question naturally arises: how can it be ascertained that the state in question is a conscious rather than an unconscious state? The absence of any testimony while such states endure makes it more plausible to consider that their occurrence is inferred rather than directly experienced. In seeking to articulate various intuitions about the nature of consciousness, one of the most common strategies in Indian philosophy is to examine the difference between waking, dreaming, and dreamless states of consciousness. While waking states provide the norm for consciousness in all its aspects, and dreaming suggests that consciousness persists beyond wakefulness, it is an open question whether consciousness persists in some latent form in dreamless sleep. Assuming the presence of an indeterminate consciousness in dreamless sleep, and perhaps of an even deeper state of consciousness beyond dreamless sleep, raises the question: how is the presence of consciousness in such states to be ascertained? The Upanișads, the principal source for this idea, fail to provide a positive account. While such states are assumed, their mode of ascertainment is not at all clear. Texts like the Māndūkya Upanișad 
(vs.7) tell us that these indeterminate states of awareness are "ungraspable... without distinguishing marks...unthinkable...indescribable" and something "whose essence is the perception of itself alone" (Olivelle 1998: 475).

Philosophers associated with the so-called "Method of Reasoning" School or Nyāya take a different view about the relation between consciousness and the self. Beginning with Gautama in the 2nd century C.E., continuing with the seminal works of Vātsyāyana and Uddyotakara in the 4 th and 5 th centuries, and concluding with the mature contributions of Jayanta and Udayana in the 9th and 10th centuries, Nyāya philosophers insist on setting more stringent requirements for ascertaining the relation between consciousness and cognition. Instead of assuming an experiential level of nonconceptual or even non-cognitive awareness, they reason that it is more apt to say that we infer the absence or presence of consciousness in states of deep sleep or swoon. We do not recollect it. In taking consciousness to be a property of the self, Naiyāyikas argue that certain necessary causal conditions must be satisfied for ascertaining the phenomenal character and content of a mental state: first, there must be contact between the sense and a given object, then, the mind must attend to the sense experience, and finally, the self must be in contact with mind (Nyāyasūtrabhāşya 2.1.14; Nyāyavārttika 2.12; Jha 1939: 124). Since Naiyāyikas reject the reflexivity thesis, cognitions can grasp an object, but they cannot grasp themselves. What makes an object-directed cognition (vyavasāya) known to the cognizing subject is not some intrinsic aspect or property of that cognition, such as its luminosity or self-reflexivity, but a second order cognition (anuviyavasāya), which takes the first one for its object (Chakrabarti 1999: 34).

But this account of the relation between consciousness and cognition is regressive: if it takes a secondary or second order cognition to make the first cognition known, then, this second cognition would require a third cognition to be known and so on. How does Nyāya answer the charge of infinite regress? Assuming cognition $\mathrm{C}_{1}$ requires a second cognition $\mathrm{C}_{2}$ does not entail that $\mathrm{C}_{2}$ itself must be made manifest by a subsequent cognition $\mathrm{C}_{3}$. Rather, $\mathrm{C}_{2}$ may do its work of making $\mathrm{C}_{1}$ known without itself becoming known unless there is a subsequent desire to manifest $\mathrm{C}_{2}$ as an instance of metacognitive awareness. On the general Nyāya rule that a cognition operates by fixing the intentionality of a token mental state, only $\mathrm{C}_{1}$ needs to be made known, for in disclosing to the individual that a cognition of a certain object has occurred, the infinite regress is blocked. In perceiving $\left(\mathrm{C}_{1}\right)$ the tree outside the window, all that a subject requires is that contact between the visual system and the object be made manifest $\left(\mathrm{C}_{2}\right)$. There is no requirement that $\mathrm{C}_{2}$ must itself be introspectively available. If Nyāya philosophers have an explanation for why their account of intentional mental states is not regressive, their understanding of the relation between consciousness and cognition is problematic. The occurrence of a primary $\mathrm{C}_{1}$ type cognition does not necessitate the occurrence of a secondary $\mathrm{C}_{2}$ type cognition. In other words, unless one is conscious and desires to know by directing one's attention to whatever is perceptually or introspectively available, cognitions that merely make their object known will never become available to the subject. But to want to know $\mathrm{C}_{1}$ by attending to what is perceptually available requires that one is already acquainted in some direct capacity with what one desires to know. For we cannot desire to know something we have no acquaintance of. For this account of cognition to work, Nyāya philosophers would have to assume the existence of pre-reflective modes of acquaintance. But such assumptions run counter to the theory (cf. Mohanty 1999: 12).

What blocks this seemingly intuitive move to ground cognition into more basic pre-predicative and pre-reflective modes of awareness is a commitment to direct realism. Indeed, one of the key features of the Nyāya theory of consciousness is that for cognition to be conscious or available to consciousness is for it to have objective content. Hence, the phenomenal character of cognition is provided by its intentional content. In cognizing a pot, both the phenomenal character 
and the phenomenal content of the cognition is provided by the object's specific features. In Lockian terms, the object furnishes cognition with both its primary and secondary qualities: that a pot is apprehended as having a particular shape, color, and weight is a function of cognition's directness toward the object and of its specific mode of apprehension. Since cognitions cannot be self-revealing or about themselves, their content is fixed by the object. At the same time, they become known only in so far as a relation between the self and the mind obtains, for although cognitions are about their object, they are made manifest only as qualities or properties (gunas) of the self. For Nyāya, then, cognition makes its object known only in so far as it presents itself as a quality of the conscious self.

What implication does the Nyāya theory of consciousness have for the mind-body problem? First, we must specify that philosophers pursuing this line of inquiry share the ontological stance of their partner school, Vaiśeșika, which admits nine types of substances and several kinds of properties in its ontology. Just as physical objects have real properties like shape, color, and mass, so also consciousness and cognition are real properties of the self, one of the nine substances of Vaiśeșika ontology. How do these different substances and properties relate or correlate? Specifically, how does Nyāya account for the properties of physical objects becoming the qualities of conscious experience? The general picture is something like this: the senses reach out and apprehend the specific properties of objects. But although these properties are disclosed by cognition, they are still the intrinsic properties of the things themselves. For example, a cognition in which the color and shape of a jar are apprehended is due to the inherence (samava $y a$ ) of the color property in the jar and to contact between the eye and the jar (Nyāyavārttika ad Nyāyasuttra 1.2.4). In other words, perception apprehends not only unique particulars, but also their properties and relations. But this epistemological solution to the question of how mental and physical properties relate or correlate is too stringent to allow for cognitive error. By itself the relation of inherence (samavaya) cannot tell whether the properties in question belong to the object or to the cognition of the object. It cannot tell us whether cognition gets its phenomenal content from the object or from itself.

\section{Consciousness without a Self: Buddhist Phenomenalism}

An altogether different line of inquiry about whether cognitive events can become instances of knowledge in the absence of a subject of knowledge is the hallmark of the Buddhist tradition. Of course, Buddhist metaphysics is well known for its rejection of a permanent self as the agent of sensory activity (Collins 1982; Harvey 1995). It is worth emphasizing that while Buddhists reject the notion of an enduring or permanent self, they do not deny the reality of the elements of existence (dharmas) (Bodhi 1993: chapter 2). But this is a metaphysics of experience (rather than of causally efficacious particulars) that takes the body to be an instrument (karana) of sensory activity, and not simply a causally determined physical aggregate. As such, the body is both the medium of contact with the world and the world with which it comes in contact (a view that finds an interesting parallel in Husserl's account of the paradoxical nature of the body as revealed through phenomenological reduction). This intuition about the dual nature of embodied awareness (as locus of lived experience) discloses a world of lived experience, whose boundaries are not fixed but constantly shifting in relation to the desires, actions, and attitudes of an agent (Husserl 1970: III, A). The question that both Buddhist philosophers and phenomenologists must address is whether intentional experiences - of the sort that disclose a world as pre-reflectively but meaningfully given-presuppose that consciousness itself, as the disclosing medium, is a knowable object.

Unlike the Naiyayikas, Buddhists typically argue that conscious cognitive events are not apprehended diachronically (or inferentially) in a subsequent instance of cognitive awareness. 
Rather, by virtue of being conscious episodes, they are inherently self-aware, even if only minimally so. Although we may intend a previous moment of conscious awareness in introspection, this retrospective apprehension of consciousness as an object cannot be its essential feature.

Let us briefly consider one of the key problems that the reductionist account of experience must necessarily confront: the project of reductive analysis, which aims to identify those elements (sensations, volitions, dispositions, patterns of habituation) that are constitutive of what we ordinarily designate as 'persons,' has an important, and perhaps unintended, consequence. It assumes that an awareness which arises in conjunction with the activity of a given sensory system is itself impermanent and momentary: visual awareness and visual object, for instance, are both events within a mental stream of continuing relations. What, then, accounts for the sense of recollection that accompanies these cognitive series? In other words, if discrete, episodic cognitive events are all that constitutes the mental domain, how does appropriation, for instance, occur? I refer here specifically to the basic mode of givenness, or for-me-ness, of our experience (Zahavi and Kriegel 2015), which presents its objects to reflective awareness.

The causal account, it seems, gives only an incomplete picture of the mental. The Buddhist Sanskrit term for cognitive awareness, vijñanna, conveys the sense of differentiation and discernment. But it is not exactly clear how such discernment also sorts between an inner and an outer domain of experience. Indeed, consciousness is not merely a faculty for discerning and sorting through the constitutive elements of experience, but is itself an event in a series of interdependent causal and conditional factors. Other than positing a continuity of awareness or a stream of mental events, early Buddhist solutions to this conundrum do not offer a satisfactory answer to how accounts of causal generation in the material domain can explain the phenomenal features of cognitive awareness.

It is largely in response to this need to provide an account for the continuity of awareness that the self-reflexivity thesis finds its first articulation in the work of the influential Buddhist philosopher Dignāga (480-540). As he claims, we must assume that cognitions are inherently self-reflexive if we are to account adequately for the phenomenal character of conscious experience. By singling out self-reflexivity as a constitutive aspect of perception, Dignāga seeks to account for the specific mode of presentation of all mental states insofar as they arise bearing a distinct mode of givenness: to perceive is to be implicitly or non-thematically present to the perceptual occasion. For Dignāga, the intentional structure of consciousness is a relational feature of its mode of presentation. Indeed, by stating that each cognitive event arises in the form of a dual-aspect relation between apprehending subject and apprehended object, Dignāga posits the aspectual nature of intentional reference (Williams 1998; Garfield 2006; Chadha 2011; MacKenzie 2011; Arnold 2012; Coseru 2012).

Unlike the Nyāya thinkers we discussed above, Dignāga and all those who follow the tradition of epistemic inquiry that he helped to initiate take the opposite view: a reliable source of cognition is to be taken, not as an instrument that makes knowledge (or the acquisition thereof) possible, but rather as the result, that is, as knowledge itself. As he notes, "a source of knowledge is effective only as a result, because of being comprehended along with its action" (Pramannasamuccaya I, 8; Hattori 1968: 97). In containing the image or aspect of its object, cognition may well appear to have a representational structure, but while appearing to comprise the act of cognizing or to enact it in some way, it is in effect nothing but the result of cognitive activity. For instance, in apprehending an object, say a lotus flower, all that we are aware of on this model is the internal aspect (äkära) of that cognitive event, or, in phenomenological terms, the intended object just as it is intended (Dhammajoti 2007). It is obvious that cognitions are contentful, but what makes them epistemically reliable is the fact that comprehension or the result of cognitive activity are nothing but cognition in its dual-aspect form. Dignāga's understanding 
of what counts as a reliable cognition comes very close to something like Husserl's notion of noematic content, or the perceived as such, which is what we get after performing the epoché or phenomenological reduction. For Dignāga, just as for Husserl, perception is ultimately constituted by intentional content: perceiving is an intentional (that is, object-directed) and selfrevealing (svaprakaśa) cognition.

Dignāga appears to be making two important claims here. First, all cognitions are selfintimating: regardless of whether an object is present or not, and of whether the present object is real or imagined, cognition arises having this dual appearance. Second, Dignāga tells us that the determination of the object, that is, how the object appears in cognition, conforms in effect to how it is intended: for example, as something desirable or undesirable. It should be possible therefore to interpret Dignāga's descriptive account of cognition as providing support for the dual-aspect nature of intentional acts. On the one hand, intentional experiences span a whole range of cognitive modalities: perceiving, remembering, judging, etc. On the other, each intentional experience is also about a specific object, whether it be something concrete, like a pot, or something imagined, like a unicorn.

What does it mean for cognitive awareness to be self-revealing? One perfectly acceptable way to answer this question is to say that self-reflexivity is a feature of each cognitive event by virtue of arising together with it. It is precisely this aspect of the Buddhist epistemologist's theory of cognition that is the main target of criticism by philosophers like Candrakirti (600-650), the champion of a particular interpretation of the scope of Middle Way or Madhyamaka philosophy. One of the axiomatic principles of Madhyamaka, as conceived by its founder, Nāgārjuna (fl. c. 150 C.E.), is that all things, including all cognitive episodes, by virtue of being the product of cause and conditions, lack inherent existence (svabhāva) and are thus empty (Mūlamadhyamaka-kārikā 3. 6-9; 4, 1-8; Siderits and Katsura 2013). In setting out to defend this principle, Candrakīrti reiterates the view that no mental state could be such as to be inherently self-presenting or selfdisclosing (Candrakīrti 1960: 62). Thus, Candrakirti's critique targets the knowledge intimation thesis, specifically the notion that there is a class of cognitive events that are essentially selfreflexive: they reveal their own character and sense of ownership without recourse to an additional instance of cognitive awareness, an object, or the positing of a subject of experience. More to the point, Candrakirti rejects the notion that reflexive awareness has this unique property of giving access to the pure datum of experience (Duerlinger 2012; Tillemans 1996: 49). Selfknowledge, on this view, is a matter of achieving a conceptually mediated understanding of what is introspectively available: instead of depending on the elusive and seemingly irreducible capacity of consciousness to make known, cognition becomes an instance of self-knowledge only metacognitively, that is, only when cognition takes a previous instance of cognition as its object.

In setting out to reject the thesis that consciousness consists in conscious mental states being implicitly self-aware, Candrakirti and his Buddhist followers share a common ground with Nyāya realists: that cognition occurs for someone is not something that is immediately available. Rather, cognition's subjective aspect is inferred from the effects of that cognition. Whereas the reflexivist thinks that I can know something only to the extent that each instance of cognition is inherently self-revealing or self-illuminating, the opponent counters that such cognitive acts as "seeing something" are transparent with regard to their own operations. If knowing is an act, we are only aware of it indirectly, when reflection turns within and toward its own operations. We see the tree outside the window, not the seeing of that tree. But we can infer that seeing has occurred for someone from the tree that is now seen.

Readers familiar with contemporary debates in phenomenology and philosophy of mind would immediately recognize these positions as versions of conceptualism versus nonconceptualism regarding perceptual content, and of the Higher-Order versus First-Order 
theories of consciousness (Janzen 2008; Gennaro 2012; Bayne 2012). In their effort to respond to the challenge posed by the Higher-Order theorists (both within and outside the Buddhist tradition), champions of the reflexivity thesis, such as Saantarakșita (725-788), turn to two main arguments: one concerning the character of consciousness and the other pertaining to the character of cognition. While sympathetic to the project of Middle Way or Madhyamaka metaphysics, and its critique of the very notion of an inherently existing entity (svabhāva), Sāntarakṣita does concede that consciousness has perforce a distinctive character that sets it apart from unconscious phenomena: it is something contrary to insentient objects. As he notes, "Consciousness arises as something that is excluded from all insentient objects. The self-reflexive awareness of that cognition is none other than its non-insentience" (Tattvasamgraha 2000; Coseru 2012: 239). This view that consciousness is contrary to insentience is meant to do double duty: on the one hand, it captures the notion that the conditions for the possibility of self-knowledge must be part of the structure of self-awareness. If self-awareness is a conceptually mediated process, then individuals who have not yet mastered a natural language or the requisite concepts of mind would lack the capacity for self-awareness. But infants and non-human animals, who lack such conceptual capacities, do behave in ways that suggest they have immediate access to their own mental states.

In taking consciousness to be something radically opposed to insentient objects, Buddhist philosophers following in the footsteps of Śāntarakșita offer an ingenious way of conceptualizing the mind-body problem. In response to a largely emergentist picture championed by the Indian 'physicalists' or the Cārvākas (Bhattacharya 2009; Coseru 2017), they propose a conception of the mind-body relation as part of a complex causal chain of dependently arisen phenomena. Simply put, the causal principle at work states that a causal relation cannot be established between two things, if changes in one do not result in changes in the other. For something to count as the effect of a cause, it must be brought about by changes in the immediately preceding instance in the causal chain. For phenomenal consciousness to be the effect of a body and its sensory organs, its presence must be causally dependent on the latter. But, as the argument goes, experience suggests otherwise. For instance, loss of cognitive function in specific domains (hearing, sight, etc.) and other kinds of sensory and motor impairment do not impact the selfreflexive character of phenomenal consciousness. Thus, phenomenal consciousness is dependent neither on the body and the senses working together, nor on each of them taken individually.

\section{Transcendental Subjectivity and the Problem of Witness Consciousness}

Tasked with providing an account of the structure of consciousness barring any metaphysical commitment to enduring or persistent selves, Buddhist philosophers, specifically those associated with the Yogācāra tradition, developed the first phenomenology of consciousness and subjectivity in Indian philosophy (Kellner 2010; Dreyfus 2011; Coseru 2012). Two key ideas in particular define this phenomenological enterprise: (i) the notion that reflexivity must be a constitutive feature of both First-Order and Second-Order cognitive events; and (ii) a dual-aspect theory of mind, which takes intentionality and subjectivity or first-personal givenness to be constitutive features of the structure of cognitive awareness. It is worth noting that the reflexivity thesis only holds for a narrow class of cognitive events, specifically those that guarantee that consciousness is unified, that despite its specialized operations and multiplicity of content consciousness presents us with a unified phenomenal field.

But while these Buddhists did not think it necessary to postulate an ontological basis for the self-reflexive dimension of consciousness, philosophers associated with Advaita-the nondualist school of thought pioneered by Sankara (c. 700-750) - do. Drawing their inspiration from the Upanișads, Advaitins take the principle of self-luminosity to its logical conclusion. 
Consciousness is no longer just an attribute of the self or a property that certain mental states have, but rather its own ultimate metaphysical ground. The Advaita theory of consciousness rests on the claim that, ultimately, mind and world are an irreducibly singular reality, in which the ultimate principle of things (brahman) and the principle of individuation (ätman) are one and the same (Bhattacharya 1973; Hulin 1978). There is nothing else besides this consciousness and its world-projecting capacities. Not only is there no ontology of mind-independent particulars, there is no ontology of subjects either. To the extent that Advaita recognizes and seeks to give an account of objects, these must ultimately belong in consciousness.

How does Advaita reconcile this conception of pure consciousness as the ultimate ground of being and what there is with our ordinary account of experience, which is irreducibly firstpersonal and embodied? Despite its seemingly radical metaphysics, the Advaita position on the phenomenology of subjectivity is quite straightforward: it is the result of an account of the sort of relations that obtain among intentional mental states when seen through the lens of consciousness's own constitutive features. The postulation of a pure consciousness lacking in any content and character would seem to preclude any attempt to offer a coherent account of intentionality, of how mental states come to be about things other than their own operations (as Avramides 2001 has convincingly argued, similarly, the Cartesian legacy of postulating privileged access to our own minds confronts us with the problem of other minds). The workaround solution is to claim that consciousness can be transitively self-reflexive about its occurrence but not about its operations. In short, for the cognition of an object to become an instance of knowledge, all that is required is for cognition to be aware that it is about an object of some kind. Its subjectivity, or subjective character, is not a matter of consciousness taking itself or its operations as an object in reflection or introspection. Rather, self-consciousness is a constitutive cognition (svarūpajñāna) of the sort that manifests as a capacity (yogyatva) whose association with mental content results in epistemically warranted cognitive events (vrttijñanna). That consciousness has this constitutive capacity to apprehend its content first-personally or through a process of 'I-making' (ahamkāra) is just what it means for consciousness to be self-luminous or self-intimating. Advaitins thus share with the Yogācāra Buddhists the view that we have immunity to error through misidentification: what the notion that consciousness is constitutively self-luminous (svatah prakassa) proves is simply that we have infallible access to the occurrence of our own mental states. It does not prove that our grasp of the content of those mental states is epistemically warranted (Gupta 2003; Ram-Prasad 2007; Timalsina 2009).

Let us consider some of the key features of this conception of consciousness, specifically as articulated by its most influential proponents-Śankara (788-820), Śrīharșa (fl. c. 12 C.E.), and Citsukha (fl. c. 1220). To begin with, the idea that consciousness becomes manifest by its own light goes back to the Upanișads, where one comes across statements to the effect that "the self itself is its light" (Bṛhadaranyaka 4.3.6; Olivelle 1998). For Śankara, what this light manifests are the contents of the mind, which cannot be known on the basis of their own operations. There is no other source of illumination besides this self, which is itself pure cognition (viśuddhavijñana) or cognition only (vijūānamātra) (Käthaupanisadbhāṣya 12-14). This conception of 'consciousness only, then, stands for the non-dual, self-reflexive awareness that is none other than the self.

In order to buttress their conception of a non-dual reflexive consciousness, Advaita philosophers use the analogy of a witness. Consider being a witness at a trial or racing event: while the experience of witnessing is immersive, it is non-participatory. The witness does not engage with the relevant actors, but simply observes from the sideline. Nor is the witness in any way affected by the outcome of the events that are witnessed. Advaitins use this analogy to make the case that cognition is an event to which consciousness simply bears witness. It is something that is made manifest by the witnessing consciousness (säkșin), not something that consciousness itself does (Brahmasūtra-bhāṣya 2.2.28; Timalsina 2009: 21). 
This parallelism between the Advaita conception of the luminosity of consciousness (svaprakāśatā) and the Yogācāra notion of self-reflexive consciousness (svasamvedana) should be obvious. Indeed, while acknowledging its deep root in the Buddhist tradition, Sriiharṣa thinks the notion that consciousness has this unique character of illuminating or revealing the operations of cognition is a self-established fact (svatahhsiddha) (Khandana Khandakhādya; Dvivedi 1990: 69). Following a line of reasoning that owes a great deal to Dharmakirti's account of reflexivity (Dharmakirti 1989: III, 485-503), Śriharșa makes the seemingly obvious point that we cannot meaningfully talk about cognitive episodes that are unknown before they are thematized, any more than we can talk about unconscious pleasure and pain. Concepts such as pleasure and pain cannot be grasped outside the phenomenal experiences that instantiate them (Chalmers 2003 makes the case that, while corrigible, phenomenal beliefs of the sort 'I am in pain' depend on phenomenal concepts that are not themselves corrigible). Similarly, the cognition of an object does not and cannot occur so to speak in the dark, without being known, as Nyāya realists and Mādhyamika Buddhists have claimed.

Debates about how best to understand the luminosity thesis are the hallmark of late Indian philosophical accounts of the relation between consciousness and cognition. Concerned with the need to provide an adequate account of the nature of reflexivity, and aware that the reflexivity thesis could be taken to entail such obviously incoherent positions as that cognition serves as its own object, Advaitins came up with different solutions. One of the most representative of such solutions comes from Citsukha, who offers a three-pronged definition of the luminosity thesis: (i) self-luminosity itself is not something that is known, on account of not being an object: (ii) self-luminosity serves as an enabling condition for consciousness's own manifestation as witnessing; (iii) self-luminosity gives consciousness its own immediacy (Tattvapradīpikā 5-6; Ram-Prasad 2007: 78). What we have here is a clear attempt to argue that, while a cognition, say of a pot, can become the object of another cognition in introspection or thought recollection, it does so by virtue of the presence of witness consciousness. The enabling condition and the immediacy clause, likewise, are meant to show that, although consciousness itself cannot form an object of cognition, it does not mean that cognition is not intentionally constituted as being about an object of some kind. Citsukha is thus concerned to preserve for the Advaitin a conception of cognition as pertaining to objects, regardless of whether these objects are taken to be ontologically discrete particulars, or simply the intentional contents of awareness. For the Advaitin, thus, the reflexivity or self-luminosity thesis is simply a statement about the unity of consciousness: whatever its nature, and however it may come to illuminate the non-cognitive (jada) processes of mental activity, consciousness itself is such that it cannot admit any duality (of 'knower' and 'known' or of 'subject' and 'object') within itself.

Advaita's non-dual metaphysics of mind would seem to preclude the sort of Cartesian phenomenology that assigns consciousness to the internal domain of thought, while postulating an external world of objects (Descartes 1996: 75ff.). Rather than arguing that the mind-body problem is ill conceived, because our experience of objects is not a phenomenon external to the mind, the Advaitin might be seen as arguing for a different conception of the hard problem. The really hard problem, on this account, is not to explain how consciousness could arise from something insentient such as the body. Rather, the problem is why consciousness, as the "light up" or illuminating aspect of mind, cannot itself become an object.

\section{Conclusion}

Indian philosophy is host to a rich tradition of reflection about the nature of consciousness, that incorporates both causal theories of mental content and detailed phenomenological analyses of 
the structure and operations of consciousness and cognition. While there is no clear indication that Indian philosophers conceived of something analogous to Descartes' mind-body problem, their solutions to the problem of agency, the problem of self-consciousness, and the problem of personal identity offer new ways to conceive the experiential features of our surface and deep phenomenology, a naturalistic epistemology grounded in pragmatic rather than normative concerns that echoes recent developments in embodied and enactive cognitive science, and a sophisticated conceptual vocabulary for thinking about the mind and mental phenomena in both egological and non-egological terms.

\section{Note}

1 For an interesting contrastive analysis with how classical Western metaphysics, specifically in the Neoplatonic tradition, conceives of the function of consciousness, see Hacker (1977).

\section{References}

Arnold, D. (2012) Brains, Buddhas, and Believing, New York: Columbia University Press.

Avramides, A. (2001) Other Minds, London: Routledge.

Bhattacharya, K. (1973) L'àtman-Brahman dans le bouddhisme ancien, Paris: École Française d'Extrême Orient. Bhattacharya, R. (2009) Studies on the Cārvāka/Lokāyata, Florence: Società Editrice Fiorentina.

Bodhi, B. (1993) A Comprehensive Manual of Abhidharma, Kandy: Buddhist Publication Society.

Candrakānta (1991 [1869]) Vaiśeșika-sūtra-bhāṣya,Varanasi:Vyasa Publishers.

Candrakīrti (1960) Prasannapadā, in P. L. Vaidya (ed.) Madhyamakaśästra of Nāgārjuna with the Commentary Prasannapada by Candrakīrti, Dharbanga:The Mithila Institute.

Chadha, M. (2011) "Self-Awareness: Eliminating the Myth of the 'Invisible Subject'," Philosophy East and West 61: 453-467.

Chakrabarti, K. K. (1999) Classical Indian Philosophy of Mind, Albany, NY: SUNY Press.

Chalmers, D. (2003) “The Content and Epistemology of Phenomenal Belief," in Consciousness: New Philosophical Perspectives, Oxford: Oxford University Press.

Collins, S. (1982) Selfless Persons: Imagery and Thought in Theravāda Buddhism, Cambridge: Cambridge University Press.

Coseru, C. (2012) Perceiving Reality: Consciousness, Intentionality, and Cognition in Buddhist Philosophy, New York: Oxford University Press.

Coseru, C. (2017) "Consciousness and Causal Emergence: Śāntarakșita Against Physicalism,” in J. Ganeri (ed.) The Oxford Handbook to Indian Philosophy, Oxford: Oxford University Press.

Descartes, R. (1996) Meditations on First Philosophy: With Selections from the Objections and Replies, edited by J. Cottingham (2nd ed.), Cambridge: Cambridge University Press.

Dhammajoti, K. L. (2007) “Ākāra and Direct Perception,” Pacific World Journal 3: 245-272.

Dharmakīrti. (1989) Pramānavārttika, ed. P. C. Pandeya, Delhi: Motilal Banarsidass.

Dreyfus, G. (2011) "Self and Subjectivity: A Middle Way Approach," in M. Siderits, E. Thompson, and D. Zahavi (eds.) Self, No-Self? Perspectives from Analytical, Phenomenological, and Indian Traditions, Oxford: Oxford University Press.

Duerlinger, J. (2012) The Refutation of the Self in Indian Buddhism: Candrakirti on the Selflessness of Persons, London: Routledge Press.

Ganeri, J. (2012) The Self: Consciousness, Intentionality, and the First-Person Stance, Oxford: Oxford University Press.

Garfield, J. (2006) “The Conventional Status of Reflexive Awareness: What's at Stake in a Tibetan Debate?” Philosophy East and West 56: 201-228.

Gennaro, R. (2012) The Consciousness Paradox: Consciousness, Concepts, and Higher Order Thoughts, Cambridge, MA: MIT Press.

Gupta, B. (2003) Cit: Consciousness, New Delhi: Oxford University Press.

Hacker, P. (1977) "Cit and Nous," in Kleine Schriften, edited by L. Schmithausen, Wiesbaden: Franz Steiner Verlag.

Harvey, P. (1995) The Selfless Mind: Personality, Consciousness and Nirvāna in Early Buddhism, Richmond, Surrey: Curzon Press. 
Hattori, M. (1968) Dignāga, on Perception, Cambridge, MA: Harvard University Press.

Heidelberger, M. (2003) “The Mind-Body Problem in the Origin of Logical Positivism," in P. Parrini, W. C. Salmon, and M. H. Salmon (eds.) Logical Empiricism: Historical and Contemporary Perspectives, pp. 233-262. Pittsburgh, PA: University of Pittsburgh Press.

Hulin, M. (1978) Le Principe de l'ego dans la pensée indienne classique: La Notion d'ahamkāra, Publication de l'Institut de Civilisation Indienne, Paris: Diffusion

Husserl, E. (1970) The Crisis of European Sciences and Transcendental Phenomenology, Translated by David Carr. Evanston, IL: Northwestern University Press.

Jaworski, W. (2016) Structure and the Metaphysics of Mind: How Homomorphism Solves the Mind-Body Problem, Oxford: Oxford University Press.

Jha, Ganganatha, trans. (1939) The Nyāya-sūtras of Gautama.Vols 1-4. Delhi: Motilal Banarsidass.

Kellner, B. (2010) "Self-Awareness (Svasamvedana) in Dignāga's Pramānsamuccaya and -vrtti: A Close Reading," Journal of Indian Philosophy 38: 203-231.

Lowe, E. J. (2006) "Non-Cartesian Substance Dualism and the Problem of Mental Causation," Erkenntnis 65 (1): 5-23.

MacKenzie, M. (2011) "Enacting the Self: Buddhist and Enactivist Approaches to the Emergence of the Self," in M. Siderits, E. Thompson, and D. Zahavi (eds.) Self, No-Self? Perspectives from Analytical, Phenomenological, and Indian Traditions, Oxford: Oxford University Press.

Nagel, T. (1974) "What Is It Like to Be a Bat?" Philosophical Review 83: 435-450.

Siderits, M. (2015) Personal Identity and Buddhist Philosophy: Empty Persons, Burlington,VT: Ashgate.

Tillemans, T. (1996) "What Would It Be Like to Be Selfless? Hīnayānist Versions, Mahāyānist Versions and Derek Parfit,” Études Asiatiques / Asiatische Studien 50: 835-852.

Timalsina, S. (2009) Consciousness in Indian Philosophy: The Advaita Doctrine of 'Awareness Only', London: Routledge.

Williams, P. (1998) The Reflexive Nature of Awareness, London: Curzon Press.

Zahavi, D. and Kriegel, U. (2015) “For-me-ness: What It Is and What It Is Not," in D. Dahlstrom, A. Elpidorou, and W. Hopp (eds.) Philosophy of Mind and Phenomenology: Conceptual and Empirical Approaches, London: Routledge.

\section{Related Topics}

Consciousness in Western Philosophy

Consciousness and Conceptualism

Consciousness and Intentionality

Meditation and Consciousness

The Unity of Consciousness 